\title{
A HISTORY TEACHER EDUCATOR'S REFLECTIONS AFTER CLASSROOM OBSERVATIONS: THE NEED FOR MULTI-PERSPECTIVES, ORAL HISTORY AND HISTORIOGRAPHY IN A HISTORY METHODOLOGY COURSE
}

\author{
DOI: http://dx.doi.org/10.17159/2223-0386/2016/n16a1 \\ Reville Nussey \\ Muckleneuk campus, University of South Africa \\ rnussey@gmail.com
}

\section{Abstract}

Given current debates about South Africa's contested past, how could teacher educators address this issue with preservice teachers so that their historical understanding develops and they present a multi-perspective view of history in practice? The underlying problem this question raises is how to shift teachers' approaches to history teaching from one that splits "fact" and interpretation in a one-dimensional account, to a multi-perspective view which acknowledges the interrelationship of interpretations and "facts". This article's purpose is to reflect on what I learnt for my own practice as a teacher educator after I observed eight practising teachers, who were former preservice teachers, teach an oral history task. The results of this research led me to propose changes to a history methodology course. I suggest firstly that preservice teachers scrutinise claims to "the truth" in oral history accounts through the "sins" of memory, which they use to re-examine "the truth" claims in their personal oral history tasks. Secondly, by exploring major developments in South African historiography, this provides a framework that shows how multi-perspectives arise and how the "politics of interpretation" informs the different "schools" of historiography. This process helps the preservice teachers examine the interrelationship between some of the "big" ideas found in historiography with the "small" ideas in their oral history tasks. It also aims to plant the seeds of doubt about history being a fixed body of knowledge, so that the preservice teachers might present a multi-perspective view of history once they become practising teachers. Adapting this process to their own context could provide a way for teacher educators in other countries to address similar issues with preservice history teachers.

Keywords: History teacher educator; Historiography; Multi-perspective past; Memory; Oral history; Preservice History teachers; Practising History teachers. 


\section{Introduction}

In 2015 a newspaper letter and a report called for different historical perspectives to be taught at South African schools. The former, from a post-colonial perspective, stressed "Africans as the subject, not the object" (Mosalakae, 2015); the latter, from an Afrikaner perspective, claimed that Afrikaner history was being ignored in favour of a history of "the struggle" (Nel, 2015). The context for these different views was one of the calls to make history a compulsory school subject for the Further Education and Training (FET) phase (Grades 10-12) in May 2015. ${ }^{1}$ These differing views about what history should be taught in schools shows how contested the South African past is in the public domain of a post-conflict country.

A problem that underpins the above debate is the way that history is frequently taught in South African schools, where many history teachers present the subject as a fixed body of knowledge, where there is a split between "fact" and interpretation. I observed this split in some primary school history classrooms ${ }^{2}$ with the way that many teachers focused on the "facts" from their pupils' oral history tasks based on themes related to apartheid. There was no acknowledgement by the teachers of the interpretative framework that underpinned the establishment of these "facts", or that alternative interpretations were possible. This means that there is a need to include multi-perspectives, defined as "a notion of a plurality of perspectives [which] may refer to both diversity of past historical perspectives as well as diversity of present understandings of the past" (Klein, 2010:615) in the history classroom. There is support for a multi-perspective approach in the current curriculum (Department of Education (DBE), 2011:12), but the difficulty lies in translating this approach into practice. This led me to pose the following research question: how could teacher educators address these competing claims about a multi-perspective South African past with preservice history teachers in a manner that develops their historical understanding and affects their practice in history classrooms?

The above question raises issues regarding history education that are broader than the South African context. Some historians and teacher educators in other countries have suggested that part of the answer lies in exposing

1 The call for history to be made compulsory for the FET phase has led to the establishment of a History Ministerial Task Team to investigate this possibility as well as other issues related to history in the curriculum (Government Gazette no 39267, 9 October 2015).

2 The classroom observations were conducted in two public primary schools and one independent school in Johannesburg between 2009 and 2011. Eight teachers who taught from Grades 4 to 7 were observed. 
preservice teachers to the disciplinary underpinnings of history (Yilmaz, 2008; Fellace, 2009; Parkes, 2011). In this article, I argue that reviewing an oral history assignment, based on a topic such as "Life before and after 1994 in South Africa", has the potential to develop a more in-depth understanding of the discipline with preservice teachers. But there is a need to make the disciplinary connections explicit by exploring some of the issues that affect the claims to knowledge that oral history makes within the discipline, and by linking the preservice teachers' oral history narratives to an understanding of aspects of historiography. Yilmaz (2008:167) both defines and gives a reason for doing historiography with teachers in the following way: "Because historiography deals critically with historical accounts of the past or modes of historical writing over time through philosophical, methodological, and epistemological questions, it can help teachers develop a sophisticated conception of history". This can also apply to preservice teachers.

The importance of historiography is acknowledged in the discipline of history, but it is part of an ongoing, highly contentious debate, which is beyond the scope of this article to discuss in detail (Evans, 1997; Eley, 2005; Jenkins, 2009; Munslow, 2012; Van Eeden, 2016). But linking some of the debates in historiography to the preservice teachers' oral history tasks, presents an opportunity to contextualise these debates and to explore the possible ramifications for teaching history in the classroom.

The purpose of this article is to reflect on the final part of my narrative inquiry (Clandinin \& Connolly, 2000), as to what I learnt as a result of this research for my own practice as a history teacher educator, and to explore the broader implications of addressing a multi-perspective past with preservice teachers via historiography and oral history

\section{Background}

Some teacher educators (McCardle \& Edwards, 2006; Johnson, 2007) claim that the doing of oral history in social sciences courses helps to position preservice teachers as historians. But this is done in the sense that they begin to understand the way that oral history interviews become, in Field's (2008a:1) definition, "dialogues about memory ... [and that] ... there are multiple ways of interpreting memories and stories that reveal the nuances of subjectivity, agency and identity formation". There is an additional claim. McCardle and Edwards (2006:232) found that using oral history provided an experience 
of learning how "to be effective educators by being engaged in learning and teaching experiences originating in effective practices". They also suggested that it would be important to do further investigation as to whether the doing of oral history tasks with preservice teachers had any effect on these teachers once they became practising history teachers.

There is research that has followed preservice teachers into the history classroom in order to examine the effects of history methodology courses on their practice (Martell, 2013; Barton \& Levstik, 2015), but there is little evidence of research into how the doing of oral history assignments with preservice teachers has affected their practice once they became teachers at schools. This was one of the reasons why I followed eight former preservice primary school teachers into their history classrooms at three primary schools in Johannesburg once they became practising teachers. I observed these teachers teaching oral history tasks that they devised themselves on topics of their choice, and interviewed them after their lessons. One of the results of these observations was the finding that the doing of oral history tasks during their history methodology courses at university had mixed results on these teachers' teaching practice once they became in-service teachers (Nussey, 2013). This led me to consider alternative ways to shift history teachers' practice, and in the next section, I consider the implications of the proposal to incorporate historiography in history education.

\section{Historiography in history education}

The proposal to use historiography in history education elicits views both in favour and against this idea. In the South African context, Kallaway (2012) has suggested that historiography should be included in the school curriculum. Ludlow (2012) has argued that the omission of historiography in the current curriculum is problematic, and demonstrated how historiography could be introduced in practice by applying it to sections on Ghana with secondary school learners. Internationally, there are those who favour including historiography in history education, like the historian Parkes (2011:102), who has argued that the "historiographer's gaze" be included in the teaching and learning of history. The reason he gives is that "historiography as a metatheoretical discourse ... extends the gaze of the historian to everything, even themselves, revealing the historical specificity of all forms of historical knowledge and practice". In the American context, Fellace (2009) described the ongoing development of a course with preservice history teachers, which showed some of the challenges and successes of 
making explicit the links between historiography and pedagogy. He argued that this application showed how Shulman's idea of pedagogical content knowledge could be implemented with some preservice history teachers. But fellow Americans Barton and Levstik (2004) have questioned the idea that the more preservice or practising teachers know about the discipline of history, the better teachers they will make. On the basis of their own classroom observations and other research with preservice and practising history teachers, Barton and Levstik (2004) present a counter-argument which suggests that what history teachers do in the classroom is very different to the practice of historians. Despite a few exceptions, irrespective of exposure to ideas concerning the interpretative nature of history in their methodology courses, Barton and Levstik (2004:252-253) found that in practice most teachers focus on "coverage" of the history curriculum and "classroom control" over their students. This means that these teachers usually adopt a "facts only" approach to the teaching and learning of history.

One of the results of my observations of the use of various oral history tasks in the primary school classroom supported Barton and Levstik's view that teachers' practice emphasises the "facts" that the pupils found out about the past. The teachers did not discuss possible interpretations of the oral evidence during their classes that I observed. In some cases, the results of the various oral history tasks devised by the different teachers were dealt with extremely superficially. In addition, many of the teachers hardly addressed the emotional impact on the pupils of having heard stories that they did not know previously about their families or community, especially when controversial issues were raised about apartheid. Another concern was that many of the pupils seemed to accept the results of their oral history interviews as "the truth", and some of the teachers revealed a limited ability to contextualise or help the pupils to interrogate their respective oral history tasks in any depth.

\section{Implications for a history methodology course}

After reflecting on my classroom observations, I realised that this research in primary school history classrooms indicated that there were gaps in my approach towards doing various oral history tasks with the practising teachers when they were preservice teachers doing a methodology course. The debate in the literature concerning changing teachers' practice in the history classroom suggested an approach which included more disciplinary knowledge (Yilmaz, 2008; Fellace, 2009; Parkes, 2011) and one which encompassed a bigger purpose to the teaching history in the classroom, where "students should 
learn history to contribute to a participatory, pluralistic democracy" (Barton $\&$ Levstik, 2004:259). There are merits to both approaches, but I wondered whether an alternative way might also be possible. It would start with some "big" ideas, such as the question of claims to "the truth", using examples from other disciplines, then, specifically in relation to oral history and a few examples in the South African context. Next, it would use these ideas as a way of debriefing the preservice teachers' oral history tasks, which had been completed during their history methodology course. Applying these ideas to a "smaller", more personal sphere could encourage the preservice teachers to reflect on the claims to "the truth" in their own and their peers' oral history assignments. Finally, engaging with some issues related to South African historiography could enable the preservice teachers to examine to what extent their oral histories challenged or fitted into the broader narratives within the South African context.

As a teacher educator, my main aim in these discussions and activities is to destabilise the notion that history is a fixed body of knowledge by exploring the interrelationship between "the truth" and oral history, interpretation and "fact", and then to discuss the implications of these ideas for history teaching in the classroom. I suggest that by linking some of these complex ideas within the discipline to the preservice teachers' oral histories, that is, by relating "big" ideas to the "smaller" personal sphere and vice versa, there is a greater chance of changing the way preservice teachers approach history teaching in the classroom. In the next section, I start with a discussion of some of the issues concerning "the truth" and its relationship to oral history as examples to show how I would approach these topics with preservice teachers.

\section{"The truth" and oral history}

To illustrate some of the concerns about the relationship between "the truth" and oral history, I will use two examples found in other fields, namely, philosophy and fiction, with the preservice teachers. This provides a breadth to this process as it shows that questions about "the truth" cut across disciplines in terms of claims to knowledge, and that this is not only a concern within the discipline of history. But I will relate the issues raised by these examples from other fields to examples within the South African context, and then encourage the preservice teachers to re-examine their own oral histories and their peers' oral histories by engaging with these ideas. 


\section{Eyewitness accounts}

The first example concerns an encounter between two eminent twentieth century philosophers, namely Ludwig Wittgenstein and Karl Popper. The latter had been invited to give a presentation at a meeting of a group of philosophers at Cambridge in October 1946, and Wittgenstein was in the audience. The conversation about philosophical issues became heated between the two men. According to Edmonds and Edinow (2001:2), in Popper's autobiography (published in 1974), he "recalled that Wittgenstein 'had been nervously playing with the poker', which he used 'like a conductor's baton to emphasize his assertions', and when a question came up about the status of ethics, Wittgenstein challenged him to give an example of a moral rule. [Popper] replied, 'Not to threaten visiting lecturers with pokers.' Whereupon Wittgenstein, in a rage, threw the poker down and stormed out of the room, banging the door behind him". However, Popper's version of what happened was dismissed as false by supporters of Wittgenstein who were present at the meeting in 1946. Edmonds and Eidinow (2001:3) observed: "There was a delightful irony in the conflicting testimonies. They had arisen between people all professionally concerned with theories of epistemology (the grounds of knowledge), understanding and truth. Yet they concerned a sequence of events where those who disagreed were eyewitnesses on crucial questions of fact". This example showed how what happened at an event many years ago continues to be contested in the present by a protagonist and eyewitnesses. It also showed how whether you were a supporter of Popper or Wittgenstein led to differing perspectives concerning the "facts" of what happened. This incident demonstrates how multi-perspectives can arise, as well as how difficult it is to establish "the truth" of what happened based on the memories of eyewitnesses who were present at an event.

According to Daniel Schacter (2001:4-5), a professor of psychology, there are "seven 'sins' of memory", which include the sins of omission, such as "transience [which] refers to a weakening or loss of memory over time", and the sins of commission, for example "bias reflects the powerful influence of our current knowledge and beliefs on how we remember our past". Judging from the above incident, it appears that the nature of the event was so significant that "transience" might or might not be at play. Popper's opinion revealed a strong possibility of "bias", as is the case with both his and Wittgenstein's supporters. But to what degree does "the truth" matter regarding these different memories about this incident? To the people involved in the dispute, it clearly did, but 
there was more at stake than "the truth" of the differing memories, because it was part of a broader dispute about the meaning of philosophy. How does this relate to the challenges of "the truth" in oral history in the South African context?

There are similar issues regarding the disagreement of eyewitness accounts found in South African history, such as the oral testimony given during the hearings at the Truth and Reconciliation Commission (TRC). For example, there were conflicting testimonies at the TRC between the security police and the askaris (ANC operative "turned" by the South African security forces) as to how the men known as the PEBCO Three were killed in 1985 (Cherry, 2000:137-138). As a result the TRC did not grant amnesty for the applicants. As Cherry (2000:143) commented about this example from the TRC, "it may be more valuable to see historical truth as a continually unfolding process not something that is past but something that is still part of the present, still contested and under construction". It is unclear to what extent the differing views on how the PEBCO Three died are an example of the sins of transience and/or bias in memory, where the fear of blame in the present might have blurred some of the participants' recollections.

\section{Memory}

The second example concerning the challenges of memory and "the truth" in oral history, comes from a novel by Donna Leon (2011:65-66). Guido Brunetti, Commissario di Polizia of the city of Venice, and his colleague and friend, Inspector Vianello are walking through Venice on their way to interview a witness after a murder:

As they reached the top of Ponte San Antonin, Brunetti pointed with his chin at the church and said, 'My mother always used to tell me, whenever we passed here, about some time in the nineteenth century - I think it was - that a rhinoceros - or maybe it was an elephant - she told me both versions - somehow ended up trapped inside the church.'

Vianello stopped and stared at the façade. I never heard anything about that, but what could a rhinoceros have been doing, walking around the city? Or an elephant, for that matter.' He shook his head, as if at yet another tale of the strange behaviour of tourists, and started down the steps on the other side. 'I was at a funeral there once, years ago.' Vianello stopped walking and looked at the façade with open surprise. 'Isn't that strange? I don't even remember whose funeral it was.' 
They continued, following the curve to the right, and Vianello said, returning to what Brunetti had told him, 'It makes you understand why nothing's ever clear, a story like that.'

'You mean the rhinoceros? That was or wasn't there? And that was or wasn't a rhinoceros?'

'Yes. Once it gets said, someone will believe it and repeat it, and then hundreds of years later, people are still repeating it.'

'And it's become the truth?'

'Sort of,' Vianello answered, sounding reluctant. They walked in silence for some time, and then he observed, 'It's pretty much the same today, isn't it?'

\section{'That stories aren't reliable?' Brunetti asked.}

'That people invent stories, and then after a time there's no telling what's true and what isn't.'

This extract clearly illustrates some of the problematic issues associated with memory and oral history, such as the sin of "absent mindedness [which] involves a breakdown at the interface between attention and memory" (Schacter, 2001:4), when Vianello cannot remember whose funeral he attended at the church. This passage also shows the creative interaction between individual memory and the community's collective memory as to whether the animal in the cathedral was an elephant or a rhinoceros, and the inventiveness and mutability of stories in the present and past, which help to create a mythical past. This means, like Vianello, we are left to wonder how to distinguish between "what's true and what isn't".

A well-known Italian oral historian, Portelli (quoted in Field, 2008b:8), has offered the following defence of oral history in relation to truth: "Oral history approaches truth as much when it departs from the 'facts' as when it records them carefully, because the errors and even the lies reveal, under scrutiny, the creative processes of memory, imagination, symbolism and interpretation that endow events with cultural significance". Portelli appears to accept that it is possible to distinguish between "the truth" and "errors" in oral history, but his notion of "truth" is qualified by his verb "approaches" which suggests that it is never possible to reach an absolute truth. In a similar way, the example of the rhinoceros/elephant in the Venetian cathedral shows the creative interaction between individual and collective memory, and the impossibility of establishing an absolute truth about either the animal or whether the event even occurred. 
In the South African context, an example of the creative interaction between individual and collective memory was shown in an oral history project conducted in Mamre in the Western Cape. According to Ward and Worden (1998:209-211), Mamre was originally a Moravian mission station where Khoisan soldiers and their families were based under the British government in the early 19th century. However, after the emancipation of the slaves in 1834, the town grew as former slaves flocked to the mission station. By the end of the 19th century, the descendants of the Khoisan and Slaves had intermarried, but when present-day residents were questioned about their ancestors in an oral history project, there was either denial or amnesia about their slave heritage. This might be another example of "bias" in memory, because of the present attempt to rewrite history, either consciously or unconsciously, in an attempt to eradicate a "shameful" past. It is possible to establish the truth concerning the slave heritage of this community by examining birth and marriage registers (Ludlow, 1992).

However, according to Abrams (2014), there has been a shift in oral history away from a focus on establishing only the veracity of the account in an oral history interview. This change makes oral history less of a "memory test" for the interviewee, and it is not only about an interest in "what' is said but 'how' and 'why' it is said" [italics in the original] (Abrams, 2014:90). Thus there is a shift in understanding towards the importance of subjectivity in oral history. Put another way, "[t]he focus of historical analysis shifts from the notion of memory as either 'true' or 'mistaken', to an emphasis on memory as process, and how to understand its motivation and meaning" (Hodgkin \& Radstone, 2003:4). Using the example of the Mamre oral history project, this could mean that it is not so important that members of this community are in denial that some of their ancestors were slaves. Instead, what counts is an exploration of the reasons for this amnesia in the present. According to Portelli (quoted in Field, 2008:8), the oral historian's role is to subject the entire process of an oral history interview to "scrutiny", although he did not explain exactly what he meant by this term. But when applied to the Mamre example, the oral historian's scrutiny not only includes identifying the omission of the slave heritage from the oral history interviews, but also the reasons that underpin this omission from the community's collective memory.

\section{Implications of the above discussion for an oral history task}

The application of the oral historian's role of "scrutiny" encourages a 
sceptical attitude towards the claims to truth made in oral histories, both in the preservice teachers' own accounts as well as those of their peers. This approach enables the preservice teachers to question what their interviewees said during the oral history interviews, and not to accept something simply because a trusted adult was an eyewitness to events. Yet "what" is said remains important in an oral history interview, especially in the South African context, where more research is required to address the many gaps in the historical record. Another reason why "the truth" matters in South Africa is the claim that it was "a society founded on the lies of the privileged" (Walker, 2001:61). There is also the need to compare and contrast oral histories with other sources too in order to identify the "sins of omission and commission" in memories of the past which are found in many oral history interviews.

The shift to the subjective nature of memory, which focuses on the creative interaction between individual and collective memory means "rather than accepting all memory as true, oral history considers what people remember, what they forget, and what they get wrong" (Ritchie, 2015:124). Yet this change in favour of a focus on subjectivity in oral history reveals another layer of complexity regarding "the truth", which needs to be carefully unpacked with preservice teachers. A difficulty with this latter approach is that it might lead to a view of "the truth" in oral history that supports a view that "anything goes". This is problematic, because this path could lead, for example, to Holocaust denial, and possibly a denial of the effects of apartheid too. An example of Holocaust denial was shown in the trial of David Irving when he sued Deborah Lipstadt for libel, because "[i]n her book Denying the Holocaust, Lipstadt had accused Irving of twisting historical evidence 'until it conform[ed] with his ideological leanings and political agenda” (Guttenplan, 2002). I observed an example of apartheid denialism in a classroom when a boy reported that his interviewee stated, "but during apartheid ... the transport system was better, the level of education was higher ... certain things about apartheid were good actually". The qualification was not made that this statement may have applied to white people under apartheid, but it was certainly not the experience of the majority of black people who suffered under apartheid laws. This example is not an isolated one, as this kind of discourse is sometimes heard among some members of the broader community.

The issues raised by establishing "the truth" in oral history highlight aspects of the complex relationship between interpretation and facts. But the depth of this complexity becomes clearer when placed in the broader context of 
some of the debates within South African historiography (Van Eeden, 2016). In the following section, I begin with a personal reflection to show the value of understanding key issues within historiography for a practising teacher. Next, I turn to a broader discussion of the implications of aspects of these debates within South African historiography for preservice teachers and their future classroom practice.

\section{South African historiography: Reflections by a teacher educator}

As a practising high school history teacher during the apartheid years of the mid-1980s to early 1990s, at a public high school and then at an independent school, I tried to present differing interpretations of the past in my lessons. My aim was to expose the pupils to multiple perspectives, instead of an Afrikaner nationalist perspective, which was the one that was dominant in the history curriculum at the time. But I was haunted throughout my teaching by the following question: how do I know that what I am teaching is "the truth"? This question led me to return to university in the late 1980s to do a Master of Education, where I explored the assumptions that underpinned the various "schools"3 of South African history in a research report.

In this research report, I used aspects of Hayden White's (1978) work, where he argued that every historical account was influenced by narrative conventions, such as farce and tragedy, and these conventions affected the way an account was structured. Another key idea found in White's (1987) work was "the politics of interpretation". This concept "does not refer directly to the interpretative practices of politics itself. Instead, he uses the politics of interpretation to suggest that certain assumptions, concerning the way historical knowledge is constituted, are part of a political position" (Nussey, 1992:25). I used the politics of interpretation as a way of understanding the South African schools of history, namely the Afrikaner nationalist, Liberal and Revisionist (Marxist and Social historians) schools. By applying the politics of interpretation to these schools, I tried to identify who the favoured agent was in each account, as well as the conception of the good and just society that informed them.

The results of this research helped me to understand that there were many "truths" to be found in the differing historical accounts. It depended on where

3 The identification of "schools" of history did not imply that there was a homogeneous approach in each "school", but that there were some core assumptions that loosely united the historians who could be considered as belonging to a "school". 
a school considered South African history to start, who was identified as the main agent in the narrative, as well as the telos or goal of history. Each school offered a coherent, although different, account of the South African past. The question of how convincing each school's account was, raised another issue, as this depended on accepting a particular starting point, agent, telos and the politics of interpretation within the school. Furthermore, this did not imply that there was no agreement among these schools about the occurrence of certain key events, but there were disagreements concerning the significance of these events. For example, the arrival of Jan van Riebeeck in 1652 to establish a refreshment station for the Dutch East India Company at the Cape was perceived by the Afrikaner nationalist school as the start of South African history. In contrast, for the Revisionists, South African history started in precolonial times, and the arrival of Jan van Riebeeck signified the start of the colonial period.

This research into South African historiography provided powerful insights for my own teaching of history in the high school classroom in the early 1990s, as it helped to challenge particular myths within the Afrikaner nationalist interpretation, such as that South Africa was an empty land before the colonists arrived. I was able to highlight and discuss some of the reasons for the competing interpretations of the South African past with my pupils, but more importantly, it affected the way I taught in the classroom (I will discuss some of the implications for practice of these ideas later in the article.) This reflection on my own experience shows some of the positive effects of understanding historiography for a practising teacher.

\section{Developments in South African historiography since 1994}

The above ideas are important for preservice teachers to understand, but even more important, are the further developments in South African historiography. These shifts took place with the transition from an apartheid government to a democratic one in South Africa in 1994. This political development challenged the assumptions that informed many of the schools of historiography in a profound manner. For example, the Afrikaner nationalist telos of the rise to power and dominance of the Afrikaner "volk" was no longer coherent after 1994. Furthermore, "the TRC's unveiling of the apartheid government's cruelty dealt a virtual death blow to the paradigm" (Verbuyst 2013:23). Paradoxically, these events have led to the re-storying of the Afrikaner nationalist paradigm, as was shown, for example, by the inclusion of 
Krotoäs history. She was a Khoikhoi woman, who married a Danish surgeon, Pieter van Meerhof, and was renamed Eva. This marriage occurred during the early days of Dutch colonisation at the Cape, and their children became the ancestors of many Afrikaner families. But this past was denied and omitted in the Afrikaner nationalist account until recently. Reclaiming this history meant that this school now "owned" an African matriarch (Coetzee, 1998).

Another important idea for preservice teachers to engage with is the call for a "reconciliation history" by Etherington (cited in Stolten, 2007:40), who argued that "historians will tell their stories better if they hold the ideal of a shared history constantly in mind". Events since 1994 have allowed for a more inclusive approach to the writing of history, and when reflecting on the TRC, former Constitutional Court judge, Albie Sachs (2009:87) argued that the TRC helped to establish "a single, broad, commonly accepted narrative of the country's history" instead of a division between black and white history.

At one level the TRC has helped to establish what happened in the recent past by clarifying "who did what to whom" (in many cases), and Sachs is correct that isolated, stereotypical divisions in historical narratives are problematic. But it would be an exaggeration to refer to the TRC as achieving, as Sachs (2009:87) claimed, a "single, broad, commonly accepted narrative of the country's history". This does not take into account the politics of interpretation found in the different schools of South African historiography, nor does it acknowledge the difficulties that these competing approaches to South Africa's past are grappling with after 1994. According to Verbuyst (2013:20), "once the struggle was over, radical historians were at an ironic paradigmatic loss because the praxis linked to their discipline had lost its purpose". As Shula Marks, a well-known historian of South African history, said at a book launch of the second volume of the Cambridge University Press's History of South Africa: "South African historians now have an abundance of sources, but no agreed roadmap, or destination" (Davis, 2012). Given recent events, such as the removal of Rhodes's statue from the University of Cape Town, and the calls for the decolonisation of South African curricula at universities (Price \& Ally, 2016), there are bound to be more developments from a decolonial perspective in South African historiography (Ndlovu, 2013). 


\section{Implications of historiography for preservice teachers and methodology course}

It is important for prospective teachers to be exposed to the different schools in South African historiography, and the politics of interpretation which affected these schools in the past and continue to affect them in the present. This exposure will help the preservice teachers to understand why there are multi-perspectives about the past, how different interpretations developed in the discipline and the ways this process is influenced by (and influences) events in the broader society. But for this approach to make an impact on the preservice teachers, an explicit link needs to be made between their own oral history tasks and the different schools of historiography during the methodology course. The preservice teachers need to explore the creative interaction between an individual and community's memories, and how these oral history interviews both challenge and affirm the broader narratives found in the different schools. Linking a study of historiography to the more personal topics that an oral history task invariably covers could be a successful approach to use with preservice teachers. This process acts as a way to highlight some of these difficult issues concerning claims to knowledge, such as "the truth" within the discipline, and the omissions and commissions of memory. These abstract ideas would be contextualised and made more meaningful for preservice teachers when they relate these ideas to their own oral histories, and in turn, use the ideas found in their oral histories to interrogate the narratives found in the different schools of South African historiography.

This approach of inter-relating oral histories to historiography opens up a conversation about the relationship between interpretation and evidence. While evidence and interpretation are logically distinct, they interweave with one another: as new evidence emerges, or an event challenges a particular interpretation, then it has to shift to accommodate these changes. In addition, when a new interpretation develops, it establishes a different perspective which creates new "facts". An example of the former is the way that evidence from oral histories could challenge aspects of the broad narratives found within the different schools of historiography. While an example of the latter is the development of a post-colonial school of interpretation, which emphasises the agency of those who were colonised. This perspective leads to different "facts" about the process of colonisation being established. The importance of this process for preservice teachers is that it disrupts a conception of history as a fixed body of knowledge, where it is possible to identify the "facts" independent of interpretation. 


\section{Implications for practice in history classrooms}

It is a truism that many preservice teachers tend to teach the way they were taught at school when they become practising teachers, and " $[\mathrm{b}] \mathrm{y}$ default, many conform to traditional expectations, entering the classroom as professionals who present history just as their predecessors did; as a grand narrative or a series of 'facts' to be memorized" (Lovorn, 2012:570). But by exposing preservice teachers to ideas such as the contested nature of "the truth" as found in oral history, and by encouraging them to scrutinise their own oral history tasks (and others) during the methodology course, this helps to disrupt these preconceptions and develops their critical thinking. Furthermore, exploring the changes in historiography over time and how their oral histories both fit into and challenge some of the ideas found in South African historiography, could help to change their practice when they are full-time teachers. These ideas provide part of a preservice and practising teacher's developing toolkit. The more you teach and reflect on your teaching, the more you realise the importance of questioning the truth claims to knowledge and the value of understanding historiography for your own practice.

However, this does not necessarily mean that in the history classroom a teacher teaches ideas regarding problems of "the truth" and the different interpretations in historiography directly to pupils. Instead, these ideas inform an approach to teaching history where they affect the following: a teacher's choice of texts and/or textbooks in the classroom; how a teacher develops pupils' understanding about multiple perspectives about the South African past, which could be done through oral history tasks; the kinds of questions that a teacher asks in the classroom; and how a teacher fosters critical thinking in the classroom. An example of the latter is that while discussing an oral history task, a teacher's question shifts from a simple identification of who an interviewee is to why an interviewee holds a particular view of an event. By comparing and contrasting pupils' oral histories in the classroom, this process raises further questions as to how reliable or trustworthy the narrators are in these accounts. These open questions also affect the way that answers are assessed in the classroom both verbally and in writing by the teacher and pupils. It shifts the expectation that there is only one right answer to a question in class or in a teacher's memorandum for a test. However, the issue of assessment in history education is part of another, broader discussion.

The above examples are not an exhaustive list of the possible implications of adopting this approach for history teachers. But further research is necessary 
to establish whether the suggested approach with preservice teachers, as discussed in this article, would have these outcomes in practice for both primary and high school teachers.

\section{Conclusion}

South Africa, like many post-conflict countries, has a contested past which continues to affect the present, as was shown by the recent calls for different perspectives to be taught in the school curriculum. Despite support for a multiperspective approach in the current curriculum, the absence of historiography is a grave omission for both teachers and pupils, especially given the recent call to make history compulsory at FET level. One of the recommendations based on this research is for the inclusion of historiography in an appropriate way at all levels of history education.

Preservice history teachers need to work with multi-perspectives during a history methodology course, otherwise there is a limited chance that they will incorporate this approach in their own teaching of history. But the disciplinary connections must be made explicit: by exploring some of the issues that affect the claims to knowledge that oral history makes within the discipline, such as "the truth", teacher educators can start the conversation with the preservice teachers. Thus encouraging the preservice teachers to subject the truth claims made by their own interviewees to scrutiny, enables them to further reflect and internalise the results of this historical enquiry in a manner that could affect their own understanding and future practice.

It is also vital that the preservice teachers understand the key ideas in the different interpretations of South Africa's past by linking their oral history narratives to an understanding of aspects of historiography. They should understand, for example, the reasons for the shifts in the Afrikaner nationalist interpretation as well as the development of a post-colonial interpretation. Relating some of the "big" ideas found in historiography to the "small", more personal, ideas found in their own oral history tasks would assist the preservice teachers to contextualise their own oral histories as well as to interrogate the broad narratives found in history. This approach could help to destabilise the conception of history as a fixed body of knowledge.

Going through the above process helps to develop the preservice teachers' critical thinking and reflection, so that it becomes part of their toolkit for history teaching in the classroom. The main aim of this kind of history teaching 
is to affect the pupils' learning of history in the classroom, and this approach could also help to develop the pupils' critical thinking too. Further research is needed as to whether this suggested approach would have these effects in practice, not only in the South African context, but in different contexts too. Adapting this process to their own context could provide a way for teacher educators in other countries to address similar issues with preservice history teachers. I do not claim that this approach alone will be able to change all history teachers' practice in the classroom, but it is a possible way for a teacher educator to attempt to do so. Overall, this process might make it less easy for preservice teachers to teach history the way they themselves were taught at school.

\section{Reference List}

Abrams, L 2014. Memory as both source and subject of study: The transformations of oral history. In: S Berger \& B Niven (eds.). Writing the history of memory. London: Bloomsbury.

Barton, KC \& Levstik, LS 2004. Teaching history for the common good. Mahwah, New Jersey: Lawrence Erlbaum.

Barton, KC \& Levstik, LS 2015. Doing history: Investigating with children in elementary and middle school. 5th ed. New York: Routledge.

Cherry, J 2000. Historical truth: Something to fight for. In: C Villa Vincencio \& W Verwoerd (eds.). Looking back, reaching forward. Cape Town: University of Cape Town.

Department of Basic Education (DBE) 2011. National Curriculum Statement: Curriculum and Policy Assessment Statement. Available at http://www.education.gov.za/ Curriculum/CurriculumAssessmentPolicyStatements/tabid/419/Default.aspx. Accessed on 1 April 2012.

Clandinin, DL \& Connelly, FM 2000. Narrative inquiry. San Francisco: Jossey-Bass.

Coetzee, C 1998. Krotoä remembered: A mother of unity, a mother of sorrows? In: S Nuttall \& C Coetzee (eds.). Negotiating the past: The making of memory in South Africa. Cape Town: Oxford University Press.

Davis, R 2012. Writing South Africa's history: only for the brave. The Daily Maverick, March. Available at http://www.dailymaverick.co.za/article/2012-03-14-writing-sashistory-only-for-the-brave\#.Vzr8R_1955c. Accessed on 1 August 2015. 
Edmonds, D \& Eidinow, J 2001. Wittgenstein's poker. London: Faber and Faber.

Eley, G 2005. A crooked line. Ann Arbour: University of Michigan Press.

Evans, RJ 1997. In defence of history. London: Granta.

Fellace, TD 2009. History and teacher education: Reflections on an experimental course. The History Teacher, 42(2):205-222.

Field, S 2008a. Introduction: Approaching oral history at the Centre for Popular Memory. South African Historical Journal, 60(2):1-6.

Field, S 2008b. Turning up the volume: Dialogues about memory create oral history. South African Historical Journal, 60(2), 2008b:7-26.

Guttenplan, D 2002. "I shall tear him to shreds". The historian Richard Evans has finally found a publisher for his book about David Irving. New Statesman, July. Available at http://www.newstatesman.com/node/155988. Accessed on 15 March 2016.

Hodgkin, K \& Radstone, S 2003. Introduction. In: K Hodgkin \& S Radstone (eds.). Contested pasts: The politics of memory. London: Routledge.

Jenkins, K. 2009. At the limits of history: Essays on theory and practice. London: Routledge.

Kallaway, P 2012. History in Senior Secondary School CAPS 2012 and beyond: A comment. Yesterday \& Today, 7:23-62.

Klein, S 2010. Teaching history in The Netherlands: Teachers' experiences of a plurality of perspectives. Curriculum Inquiry, 40(5):614-634.

Leon, D 2011. Drawing conclusions. London: Random House.

Lovorn, M 2012. Historiography in the methods course: Training preservice history teachers to evaluate local historical commemorations. The History Teacher, 45(4):569579.

Ludlow, EH 1992. Missions and emancipation in the South Western Cape: A case study of Groenekloof (Mamre), 1838-1852. Unpublished MA thesis. Cape Town: University of Cape Town.

Ludlow, H 2012. Ghana, cocoa, colonialism and globalisation: Introducing historiography. Yesterday \& Today, 8:1-21.

Martell, CC 2013. Learning to teach history as interpretation: A longitudinal study of beginning teachers. The Journal of Social Studies Research, 37:17-31. 
McCardle, LW \& Edwards, CL 2006. Practising to teach: Oral history in education. Academic Exchange Quarterly, 10(2):231-236.

Mosalakae, K 2015.Teach history through African eyes. Business Day, July. Available at http:// www.bdlive.co.za/opinion/letters/2015/07/23/letter-teach-history-throughafrican-eyes. Accessed on 25 July 2015.

Munslow, A 2012. A history of history. London: Routledge.

Ndlovu, M 2013. Mobilising history for nation-building in South Africa: A decolonial perspective. Yesterday \& Today, 9:1-12.

Nel, C-A 2015. Vertel die Afrikaner se geskiedenis ook billik? Nuus 24, Julie. Available at http:// www.netwerk24.com/Nuus/Onderwys/Vertel-die-Afrikaner-se-geskiedenis-ookbillik-20150725. Accessed on 25 July 2015.

Nussey, RJ 1992. Philosophical assumptions that inform history teaching in South Africa. Unpublished MEd research report. Johannesburg: University of the Witwatersrand.

Nussey, RJ 2013. The challenges and limitations of developing a conception of a 'reconciliatory pedagogy' using oral history with South African pre-service and in-service history teachers. Unpublished $\mathrm{PhD}$ thesis. Johannesburg: University of the Witwatersrand.

Parkes, RJ 2011. Interrupting history. New York: Peter Lang.

Price, M \& Ally, R 2016. Decolonisation must not be a black and white issue. Business Day, April. Available at http://www.bdlive.co.za/opinion/2016/04/04/ decolonisation-must-not-be-a-black-and-white-issue. Accessed on 4 April 2016.

Ritchie, DA 2015. Doing oral history. 3rd ed. Oxford: Oxford University Press.

Sachs, A 2009. The strange alchemy of life and law Oxford: Oxford University Press.

Schacter, DL 2001. The seven sins of memory. Boston: Houghton Mifflin.

Stolten, H 2007. History making and present day politics. Uppsala: Nordiska, afrikaininstitutet.

Van Eeden, ES 2016. Thoughts about the historiography of veracity or „truthfulness“ in understanding and teaching history in South Africa. Yesterday \& Today, 15:3765.

Verbuyst, R 2013. History, historians and the South African Truth and Reconciliation Commission. New Contree, 66:1-26. 
Walker, M 2001. Making better knowledge: Little stories, truth-telling and social justice effects. The School Field, 12(1/2):55-68.

Ward, K \& Worden, N 1998. Commemorating, suppressing, and invoking Cape slavery. In: S Nuttall \& C Coetzee (eds.). Negotiating the past. Cape Town: Oxford University Press.

White, H 1978. Tropics of discourse. Baltimore: John Hopkins University.

White, H 1987. The content of the form. Baltimore: John Hopkins University.

Yilmaz, K 2008. Social Studies teachers' conceptions of history: Calling on historiography. The Journal of Educational Research, 101(3):158-176. 